Peter Gallo,

Ph.D., Assistant Professor, University of Presov, Slovakia

(iD ORCID: 0000-0001-5193-1997

email: peter.gallo.1@unipo.sk

Beata Balogova,

Ph.D., Professor, University of Presov, Slovakia

(iD ORCID: 0000-0001-6069-2721

email: beata.balogova@unipo.sk

Bohuslava Mihalcova,

Ph.D., Professor, University of Economics in Bratislava, Slovakia

(iD ORCID: 0000-0001-7958-3429

Corresponding author: peter.gallo.1@unipo.sk

\title{
THE INFLUENCE OF INTERCULTURAL MANAGEMENT FACTORS AS ELEMENTS OF MANAGEMENT INNOVATION
}

Abstract. In the current globalization conditions, companies operate in an open environment and constant contact with foreign managers and other interest groups. Intercultural management is an integral and important part of any international company employing and cooperating with employees from different cultures. The proper implementation of intercultural management enables the innovation of employee relations and thus supports achieving the company's goals. This paper aims to examine the influences and relations between local and foreign employees and/or managers. Research on intercultural communication and management was conducted in IT companies by collecting questionnaire data from respondents, formulating hypotheses, and examining them through the Kruskal-Wallis test. Hypotheses verification stated that statistically significant differences are in the relation between the knowledge of the company's cultural differences and the employees' years of experience. The calculated value of $p=0.04728$ proved that the longer the employees work in a company interconnecting different cultures, the greater their knowledge of its cultural differences. The research verified the hypothesis on statistically significant differences in the acceptance of cultural differences in the company concerning employee training. The result of the hypothesis verification was the value of $p=0.6539$, which did not confirm the hypothesis. The research showed that the employee training did not affect the acceptance of cultural differences. In companies with a labor force from diverse countries and cultures, disputes often arise in communication. The last formulated hypothesis concerning the issue focused on examining the relationship between the acceptance of disputes based on cultural differences in the company and the employee training. The calculated value of $p=0.1$ did not confirm this relationship. Therefore, the employee training does not affect the acceptance of disputes in the examined companies. The present research on intercultural management could expand knowledge and innovate relationships to prevent disputes in international companies.

Keywords: intercultural management, intercultural communication, international company, employees, cultural differences.

Introduction. In the 21 st century, the emergence of a new model significantly different from the model operating with raw materials, physical labor, and simple investment could be observed. Thus, the model rests on knowledge and innovation developed through people's intelligence and energy, imagination, and willingness to act as driving forces for technical, scientific, and technological advancement (MazurWierzbicka, 2019). Current globalization processes require the development and innovation of relationships and processes and the proper management of organizations by responsible and skilled employees (Bilan et al., 2019; Cabinova et al., 2020; Sokolovska et al., 2020). In the current globalization era, a growing number of companies are seconding their workers to countries that have not been perceived

Cite as: Gallo, P., Balogova, B., \& Mihalcova, B. (2021). The Influence of Intercultural Management Factors as Elements of Management Innovation. Marketing and Management of Innovations, 2, 65-73. http://doi.org/10.21272/mmi.2021.2-05 

Innovation

market opportunities until recently, sometimes due to the problematic cultural and social environment. Since joining the European Union, Slovakia has attracted foreign corporations, which decided to establish their branches in this country or build their own companies with the appropriate infrastructure. These companies often second their own managers challenged by a new environment and innovations in social systems and relationships. In this sense, it is possible to understand innovation as ties with the organization's way of life, with the people's way of thinking and acting. It follows that innovation management is deployed to achieve effective management of innovation processes in a business unit and promote teamwork, creative spirit, and vitality (Bilovodska et al., 2021). Management experts agree that employees encountering culturally diversified environments need to be equipped with intercultural competencies (Onuferova et al., 2020). Suppose these experts are unable to tackle cultural differences effectively. In that case, they leave home with the burden of failure or are more likely to remain in our country, but with reduced efficiency leading to negative phenomena. Therefore, it is of paramount importance that the employees and managers are trained in advance for the peculiarities of a given culture and could adapt flexibly, which does not mean ignoring or suppressing their own culture (DzionekKozłowska and Rehman, 2017; Bila and Kacmarova, 2018; Pietruszka-Ortyl, 2019). A quality that every seconded abroad worker should have is the ability to get along with local workers. A foreign seconded employee or manager able to get along with local employees brings benefits to their foreign shareholders and local employees through their activities and way of management by properly managing and motivating them. For better cooperation and successful management of conflicts that might arise when cooperating with people of different cultures and nations, it is necessary to acquire new intercultural management knowledge. The present paper deals with the issue under consideration while examining intercultural management in IT companies. In turn, four sections deal with the topic as follows. The first section provides the theoretical underpinnings and literature overview of the issue. Herewith, the second section describes the research methodology and the research sample of respondents. The third section presents the research results, validated hypotheses, and conclusions on the issue. The fourth section summarizes the data obtained and assessed in line with the research conducted.

Literature Review. It is undeniable that management and culture are interdependent and deeply interconnected areas. Every nation has its own culture deeply rooted in the nation's people. In turn, it passes on to other people. People spread their culture in every area of life and their work, through work habits, and themselves. Besides, like nations, every organization or company have their own culture, as employees are the foremost bearers of culture (Eisenhardt et al., 2016; Al-Musadieq et al., 2018). Mastering intercultural management, acquiring new knowledge in the field, and applying it in practice is paramount in any international company employing or cooperating with employees from other cultures.

Moreover, as the diversity of cultures anticipates both positive and negative situations, it is necessary to emphasize quality management to cope appropriately. Companies holding managers from other cultures and employing staff from different countries must necessarily perceive cultural diversity much more intensely than companies hiring employees from the same culture (Mäkelä et al., 2019). According to Aguzzoli and Geary (2014), the main task of intercultural management is to clarify the behavior of people working in organizations around the world and show them how to work in companies with employees or clients from different cultures. Ang et al. (2015) defined the essence of ever-globalizing intercultural management as the effective management and direction of synergistic interactions where knowledge, values, and experience are transferred to implemented multicultural domains. When people of different cultures (with different cultural identities) are involved in the process, they develop and apply their knowledge of various cultures in international management. Thus, it is the essence of intercultural management. Nevertheless, these people may or may not be part of the same business unit (Bailey et al., 2017; Beugelsdijk et al., 2018). Working together with professionals from different cultures and nationalities is responsible for the growth of international trade and migratory labor. Employees visibly 

Innovation

influence the success of the organization or company in which they work. Creating an effective work team in any environment is a very demanding and long-term task to accomplish. This task is much more challenging in an environment where employees from different cultures work together (Cooke et al., 2019; Caligiuri et al., 2020). Therefore, intercultural management is promoted chiefly in companies and enterprises employing people of different cultures and nationalities. Cultural values are an essential aspect in an intercultural setting. Therefore, managers have to be familiar with them and apply them appropriately and sensitively. In particular, managers should embrace both cultural diversity in a company and each employee's uniqueness. It is mandatory that managers working in an international environment be interested in their culture and language, history, geography, traditions, customs, etc. Good management is vital to the company's success since modern managers know how to increase the company standards to a higher level (Cameron, 2017; Gonzalez-Faraco et al., 2020).

The result of international trade is the current world of globalization, in which cultures get increasingly interconnected. Despite the differences in the economies of countries and regions, global trade opens up many new opportunities and poses new challenges in the business world. Since each culture is unique, in an intercultural setting, different situations may arise and reveal misunderstandings or barriers. The latter mostly relate to language differences, assumptions, and similarities, features of verbal and non-verbal communication, prejudices, stereotypes, judgmentalism, anxiety, uneasiness, and fear of meeting a person of a different culture. If individuals perceive their culture as superior to others, this is the manifestation of ethnocentrism, which is often one of the basic obstacles in an intercultural environment (Romani et al., 2018; Ferraris et al., 2018; Knapík and Balogova, 2019).

Intercultural differences (resulting from globalization) are becoming an area in which only wellinformed managers succeed. Entering the international market has differences in people's communication, thought, and behavior from different cultural backgrounds. Therefore, it is essential to accept these differences and adapt to them, especially in international teams. Therefore, an integral part of success is, first and foremost, tolerance, understanding, and acceptance of the culture in question.

Experts in the field (Leung et al., 2014; Caputo et al., 2018) claimed that cultural aspects were essential for international trade, including management. Above all, it is possible to refer to the European Union companies, which are diverse and result from labor migration bringing multiculturalism, which eventually brings about social and cultural change. In international trade, managers need to have intercultural competence, including knowing the culture with which their business is conducted. Intercultural aspects could greatly influence the business partners' behavior (Barner-Rasmussen et al., 2014; Caprar et al., 2015; Del Giudice et al., 2017).

Cultural aspects include economics, society, family life, religion, sports, food, art issues emphasizing what people do at a particular time and place. Each person is defined through their social group affiliation composed of several levels of mental programming (Primecz et al., 2016; Ristic et al., 2017; Schotter et al., 2017; Poklembova, 2019).

Methodology and research methods. The main objective of this study is to establish the major issues of intercultural management, specifically to pinpoint the hierarchical relationships between managers and employees. A questionnaire was chosen as the main research tool since it is considered the most suitable tool in this type of research. The questionnaire was divided into two basic parts. Therefore, the first part consisted of identification questions focused on the respondent's gender, training, age, and (number of) years of work experience in the organization/company. The second part of the questionnaire was research-oriented, focusing on intercultural relations between foreign managers and employees. That part consisted of multiple-choice answers, with the possibility of supplementing the answer. It was combined with Likert scale questions, five-point-scales in which respondents specified their level of agreement to a statement from strongly agree, through agree, neither agree nor agree disagree, disagree, to strongly disagree. 

Innovation

The present research was carried out online using the Google application. The respondents were selected following probability sampling, which uses statistical theory to randomly select a small group of people (sample) from an existing large population. Then, it was predicted that all respondents' responses would match the overall population and assume that everyone in the population has the same probability of being selected. The research was carried out in multinational companies in the IT sector. The approached respondents were in daily contact with foreign managers. Notably, the contact between the foreign manager and the domestic employee is crucial for the present research. Thus, a total of 676 respondents were contacted, while 150 responses were received. Therefore, the return rate of the questionnaires is $22.19 \%$. The survey was carried out based on the below-given hypotheses:

$\mathrm{H} 1$ : It is assumed that there are statistically significant differences in the knowledge of company culture concerning the employees' years of experience.

$\mathrm{H} 2$ : It is assumed that there are statistically significant differences in the acceptance of cultural differences in the company concerning employee training.

H3: It is assumed that there are statistically significant differences in the acceptance of culture difference-based disputes concerning employee training.

The study involved the mathematical-statistical methods for statistical processing of the data obtained through the questionnaire. In turn, it enabled to quantify the research results accurately. The methods of analysis, synthesis, deduction, and induction, the methods of higher statistics (than the Chi-square test of independence or the Kruskal-Wallis test) were used in this research. The obtained data were evaluated using the Kruskal-Wallis test of non-parametric statistics, an extension of the Mann-Whitney $U$ test. The test is used for three or more groups and represents a non-parametric alternative to a one-way analysis of variance. The test results are reported as a $p$-value, which must be lower than the selected level of significance $a=0.05$. With the decreasing $p$-value $(p<0.05)$, the statistical significance of the differences increases significantly. For a quick analysis and clear display of data, contingency tables were used. Thus, the relationship between the two statistical features was summarized. The statistical evaluations were performed in the Statistica version 12 software.

Results. This research focused on examining the intercultural relationships between managers and employees in multinational IT companies. In turn, the first research question focused on examining the differences in knowledge of company cultural differences concerning the employees' years of experience. The present research defined the null hypothesis $\mathrm{H} 0$ versus the alternative hypothesis $\mathrm{H} 1$, which read as follows:

$\mathrm{HO}$ : It is assumed that there are no statistically significant differences in knowing the company's cultural differences concerning the employees' years of experience.

$\mathrm{H1}$ : It is assumed that there are statistically significant differences in knowing the company's cultural differences concerning the employees' years of experience.

Table 1 shows the results of the statistical verification.

Table 1. Results of hypothesis 1 verification

\begin{tabular}{cc}
\hline Dependent variable & Knowledge of company's cultural differences \\
\hline Independent variable & Years of work experience \\
Kruskal-Wallis test & $\mathrm{H}(3, \mathrm{~N}=150)=1.9981$ \\
Formula & $H=\frac{12}{N(+1)} \sum_{i=1}^{C}\left(\frac{R 2 i}{n i}-3(\mathrm{~N}-1)\right)$ \\
Error profitability & $\alpha=5 \%(0.05)$ \\
p-Value & $\mathrm{p}=0.04728$ \\
\hline
\end{tabular}

Sources: developed by the authors. 

Innovation

Based on the evaluation of the questionnaire data, the dependent variable knowledge of the company's cultural differences concerning the independent variable employee years of experience allowed confirming statistically significant differences. The number of employee years of experience impacts the employees' knowledge of the company's cultural differences. Based on a p-value (0.04728), which is lower than the significance level $(0.05)$, the $\mathrm{HO}$ hypothesis was rejected. Thus, the statistically significant differences between the independent and dependent variables were demonstrated. In turn, the $\mathrm{H} 1$ hypothesis was accepted. It means statistically significant differences in knowing the company's cultural differences concerning the employee years of experience.

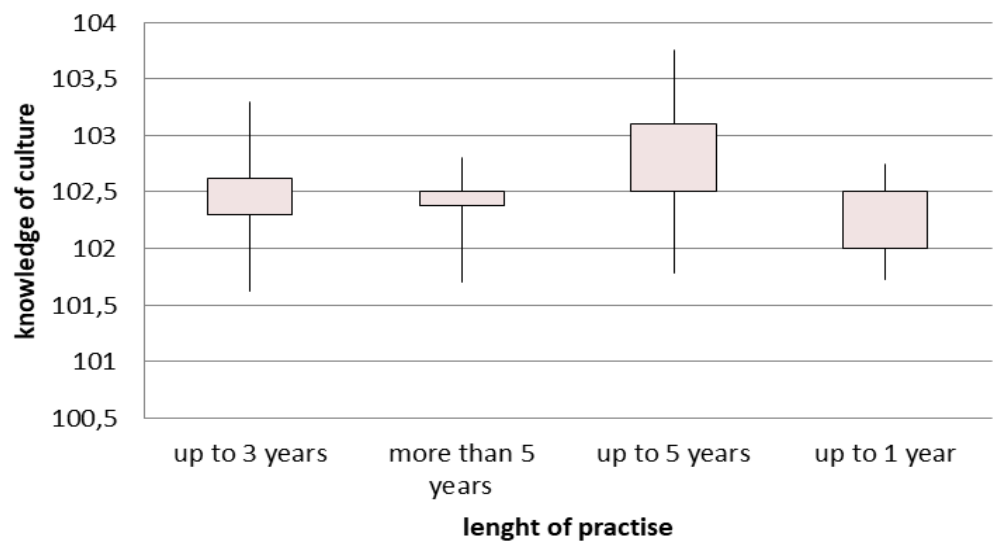

Figure 1. Box plot of hypothesis 1 by variables

Sources: developed by the authors.

Figure 1 allows concluding that none of the cases shows extreme values that could affect the test. In this case, the mean values are in the range of 102.0-103.0. The lowest lower limit is 101.6 in assessing the knowing the company's cultural differences concerning the employee years of experience up to 3 years; the highest upper limit is up to 5 years, at the limit of 103.7 .

The second hypothesis focused on examining the acceptance of the company's cultural differences concerning employee training. In this regard, $\mathrm{HO}$ and $\mathrm{H} 1$ were determined as follows:

$\mathrm{HO}$ : It is assumed that there are no statistically significant differences in accepting the company's cultural differences concerning employee training.

$\mathrm{H} 1$ : It is assumed that there are statistically significant differences in accepting the company's cultural differences concerning employee training.

Table 2 contains the results of statistical verification of the investigated hypotheses.

Table 2. Results of hypothesis 2 verification

\begin{tabular}{cc}
\hline Dependent variable & Acceptance of company's cultural differences \\
\hline Independent variable & Training \\
Kruskal-Wallis test & $H(4, N=150)=2.4486$ \\
Formula & $H=\frac{12}{N(+1)} \sum_{i=1}^{c}\left(\frac{R 2 i}{n i}-3(N-1)\right)$ \\
Error profitability & $\alpha=5 \%(0.05)$ \\
p-Value & $p=0.6539$
\end{tabular}

Sources: developed by the authors. 

Innovation

Based on the evaluation of the questionnaire data, the dependent variable of acceptance of the company's cultural differences concerning the independent variable of employee training confirmed no statistically significant differences. Employee training does not affect the acceptance of the company's cultural differences by the company employees. Based on the p-value (0.6539), which is higher than the significance level (0.05), hypothesis $\mathrm{H} 1$ was rejected as no statistically significant differences between the independent and dependent variables were demonstrated. The HO was accepted. Thus, the findings confirmed no statistically significant differences in accepting the company's cultural differences concerning employee training.

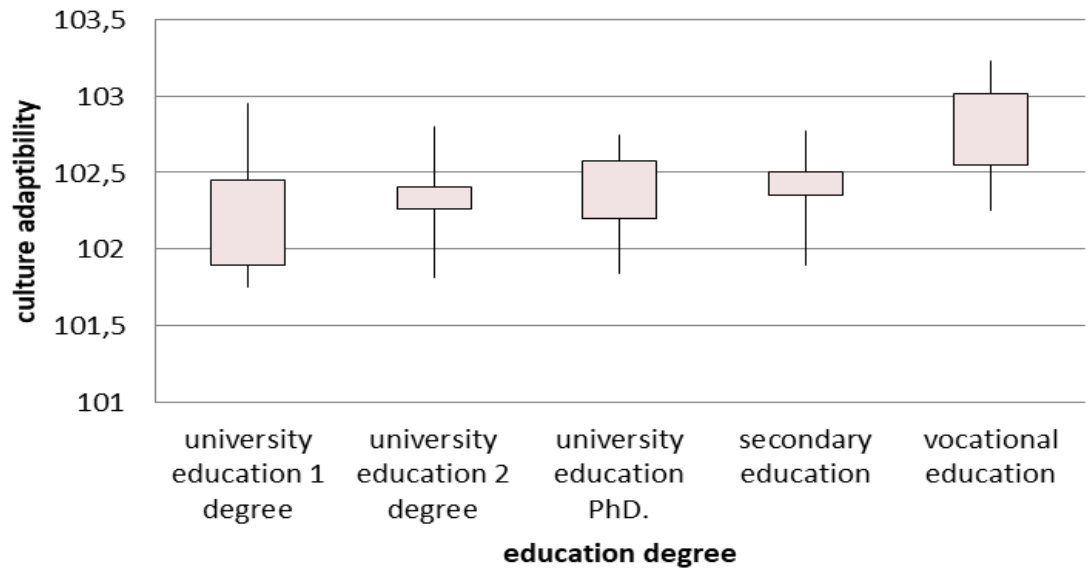

Sources: developed by the authors.

Figure 2 allows concluding that none of the cases shows extreme values that could affect the test. The mean values are the same in almost all cases and range from 102.2 to 103 . The lowest lower limit for assessing the acceptance of a company's cultural differences concerning employee training is 101.7 in higher education. The highest upper limit is 103.3 in the case of higher vocational education. The third hypothesis was focused on finding differences in settling the disputes based on the company's cultural differences concerning employee training. The following hypotheses were postulated:

$\mathrm{HO}$ : It is assumed that there are no statistically significant differences in settling the disputes based on the company's cultural differences concerning employee training.

$\mathrm{H} 1$ : It is assumed that there are statistically significant differences in settling the disputes based on the company's cultural differences concerning employee training.

Table 3. Results of hypothesis 3 verification

\begin{tabular}{cc}
\hline Dependent variable & Settling the disputes \\
\hline Independent variable & Training \\
Kruskal-Wallis test & $\mathrm{H}(4, \mathrm{~N}=150)=7.1444$ \\
Formula & $H=\frac{12}{N(+1)} \sum_{i=1}^{c}\left(\frac{R 2 i}{n i}-3(\mathrm{~N}-1)\right)$ \\
Error profitability & $\alpha=5 \%(0.05)$ \\
$p$-Value & $\mathrm{p}=0.1$
\end{tabular}

Sources: developed by the authors. 

Innovation

Based on the evaluation of the questionnaire data, the dependent variable of settling the disputes, which arise due to the company's cultural differences in relation to the independent variable of employee training, confirmed no statistically significant differences. Employee training does not affect the employees settling disputes. Based on the p-value (0.1), which is higher than the significance level $(0.05)$, $\mathrm{H} 1$ was rejected because no statistically significant differences between the independent and dependent variables were demonstrated.

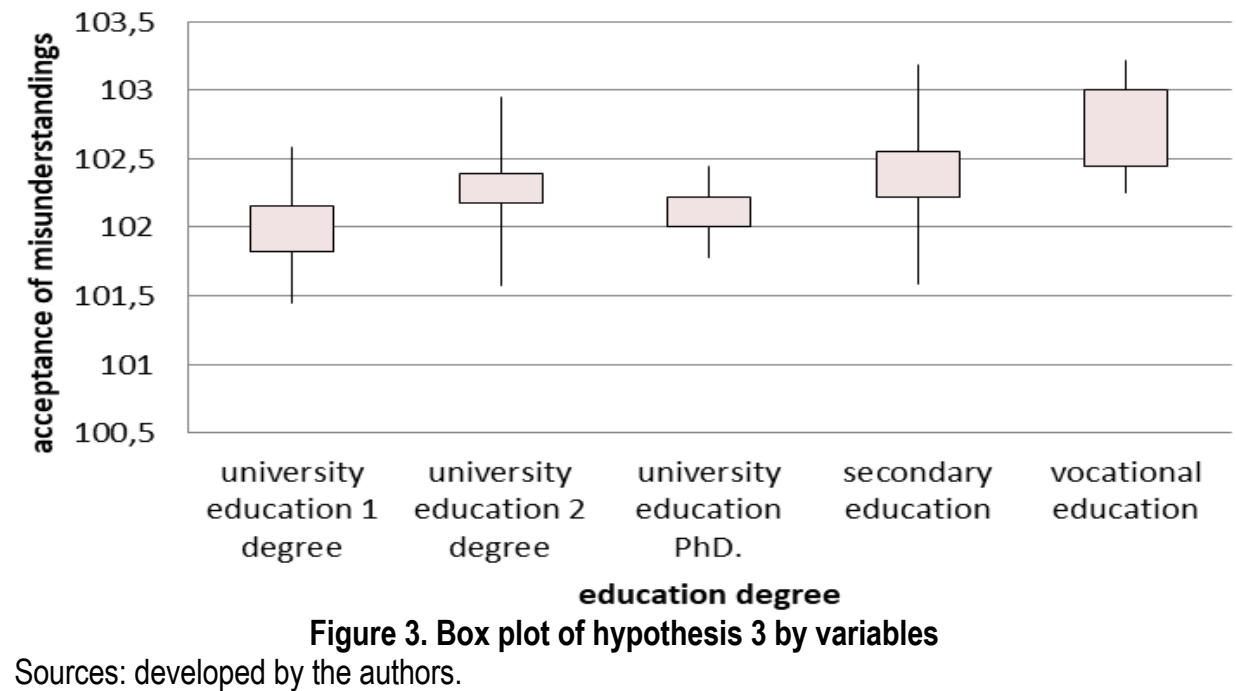

The resultant graph allows concluding that none of the cases showed extreme values that could affect the test. The mean values are the same in almost all cases and range from 101.9 to 103 . Concerning employee training, the lowest lower limit of the assessment of settling the disputes, in the case of Bachelor's degree studies, is 101.5; in higher vocational education, the highest upper limit is at the limit of 103.2.

Conclusions. The present research aimed to examine intercultural relations in companies that typically employ managers from abroad. Through hypothesis statements, the issue of intercultural communication in companies was clarified. The obtained data and their subsequent verification showed that the company's cultural differences knowledge is related to the employees' work experience length. Thus, the longer employees work in a given company, the greater their knowledge of the company's cultural differences. Besides, this research addressed the acceptance of the company's cultural differences concerning employee training. It was assumed that higher education degrees would be more inclined to accept the company's cultural differences. From the answers obtained from the respondents, this hypothesis was not confirmed. Therefore, it is possible to state that the employee training does not affect the acceptance of the company's cultural differences. Certain types of disputes often occur in organizations with employees from different cultures and countries. Therefore, this research considered whether employee training contributes to the greater degree of settling disputes between foreign and domestic employees. This hypothesis was not confirmed after verifying the data from the respondents; the received employee training does not affect the settling of disputes based on the company's cultural differences.

This research attempted to answer certain questions related to intercultural communication in companies with a combination of foreign and local employees. International companies are no rarity in 

Innovation

today's world. The almost borderless world enables travel for work and brings foreign investors to countries with different cultures. For the proper functioning of these companies, it is necessary to know the issues of intercultural management. Intercultural management also includes the knowledge and its application in preventing disputes that naturally arise in international companies. Different cultures profess different religions, speak different languages, communicate in different styles. Thus, it is important to respect these differences. Intercultural management and its proper use would help to innovate processes and relationships in the company. In turn, it contributes to achieving satisfaction not only by the owners but also by other interest groups.

Author Contributions: conceptualization, P. G., B. B. and B. M.; methodology, P. G.; software, P. G.; validation, B. M.; formal analysis, B. B.; investigation, B. B.; resources, B. M.; data curation, P. G.; writing original draft preparation, B. B.; writing review and editing, P. G.; visualization, B. M.; supervision, P. G.; project administration, B. B.; funding acquisition, B. B.

Funding: This paper is an outcome of the research project VEGA No. 1/0433/20 «Factors of formal and non-formal care in the long-term care system».

\section{References}

Aguzzoli, R., \& Geary, J. (2014). An 'emerging challenge': The employment practices of a Brazilian multinational company in Canada. Human Relations, 67(5), 587-609. [Google Scholar] [CrossRef]

Al-Musadieq, M., Nurjannah, N., Raharjo, K., Solimun, S., \& Fernandes, A. A. R. (2018). The mediating effect of work motivation on the influence of job design and organizational culture against HR performance. Journal of Management Development, 37 (6), 452-469. [Google Scholar] [CrossRef]

Ang, S., Rockstuhl, T., \& Tan, M. L. (2015). Cultural intelligence and competencies. International encyclopedia of social and behavioral sciences, 2, 433-439. [Google Scholar] [CrossRef]

Bailey, C., Madden, A., Alfes, K., \& Fletcher, L. (2017). The meaning, antecedents and outcomes of employee engagement: A narrative synthesis. International Journal of Management Reviews, 19(1), 31-53. [Google Scholar] [CrossRef]

Barner-Rasmussen, W., Ehrnrooth, M., Koveshnikov, A., \& Mäkelä, K. (2014). Cultural and language skills as resources for boundary spanning within the MNC. Journal of International Business Studies, 45(7), 886-905. [Google Scholar] [CrossRef]

Beugelsdijk, S., Kostova, T., Kunst, V. E., Spadafora, E., \& Van Essen, M. (2018). Cultural distance and firm internationalization: A meta-analytical review and theoretical implications. Journal of Management, 44(1), 89-130. [Google Scholar] [CrossRef]

Bila, M., \& Kacmarova, A. (2018). Is there anything like a universal typology of translation solutions for culture-specific items?.Folia linguistica et litteraria, 24, 67-84. [Google Scholar]

Bilan, Y., Lyeonov, S., Lyulyov, O., \& Pimonenko, T. (2019). Brand management and macroeconomic stability of the country. Polish Journal of Management Studies, 19. [Google scholar] [CrossRef]

Bilovodska, O., Kholostenko, A., Mandrychenko, Z., \& Volokitenko, O. (2021). Innovation Management of Enterprises: Legal Provision and Analytical Tools for Evaluating Business Strategies. Journal of Optimization in Industrial Engineering, 14(1), 89-96. [Google Scholar] [CrossRef]

Cabinova, V., Onuferova, E., Jurova, N., \& Fedorcikova, R. (2020). Efficiency evaluation of the medical SPA sector in Slovakia: An application of DEA method. Calitatea, 21(178), 7-14. [Google Scholar]

Caligiuri, P., De Cieri, H., Minbaeva, D., Verbeke, A., \& Zimmermann, A. (2020). International HRM insights for navigating the COVID-19 pandemic: Implications for future research and practice. Journal of International Business Studies, 51(5), 697-713. [Google Scholar] [CrossRef]

Cameron, K. (2017). Cross-cultural research and positive organizational scholarship. Cross Cultural \& Strategic Management, 24 (1), 13-22. [Google Scholar] [CrossRef]

Caprar, D. V., Devinney, T. M., Kirkman, B. L., \& Caligiuri, P. (2015). Conceptualizing and measuring culture in international business and management: From challenges to potential solutions. Journal of International Business Studies, 1011-1027. [Google Scholar] [CrossRef]

Caputo, A., Ayoko, O. B., \& Amoo, N. (2018). The moderating role of cultural intelligence in the relationship between cultural orientations and conflict management styles. Journal of Business Research, 89, 10-20. [Google Scholar] [CrossRef]

Carlos Gonzalez-Faraco, J., Gonzalez-Falcón, I., \& Rodriguez-Izquierdo, R. M. (2020). Inter-cultural policies at school: meanings, dissonances and paradoxes. Revista de Educacion, (387), 63-84.[CrossRef]

Cooke, F. L., Liu, M., Liu, L. A., \& Chen, C. C. (2019). Human resource management and industrial relations in multinational corporations in and from China: Challenges and new insights. Human Resource Management, 58(5), 455-471. [Google Scholar] [CrossRef] 
P., Gallo, B., Balogova, B., Mihalcova. The Influence of Intercultural Management Factors as Elements of Management Innovation

Del Giudice, M., Nicotra, M., Romano, M., \& Schillaci, C. E. (2017). Entrepreneurial performance of principal investigators and country culture: relations and influences. The Journal of Technology Transfer, 42(2), 320-337. [Google Scholar] [CrossRef]

Dzionek-Kozlowska, J., \& Rehman, S. N. (2017). Attitudes of economics and sociology students towards cooperation: A crosscultural study. Economics \& Sociology, 10(4), 124-136. [Google Scholar] [CrossRef]

Eisenhardt, K. M., Graebner, M. E., \& Sonenshein, S. (2016). Grand challenges and inductive methods: Rigor without rigor mortis. Academy of Management Journal, 59(4), 1113-1123. [Google Scholar] [CrossRef]

Ferraris, A., Santoro, G., Bresciani, S., \& Carayannis, E. G. (2018). HR practices for explorative and exploitative alliances in smart cities: Evidences from smart city managers' perspective. Management Decision. [Google Scholar] [CrossRef] [Link]

Knapík, J. \& Balogova, B. (2019). Value Orientation of Social Work Students. Journal Socioterapie, 5(2), 53-58. Retrieved from

Leung, K., Ang, S., \& Tan, M. L. (2014). Intercultural competence. Annu. Rev. Organ. Psychol. Organ. Behav., 1(1), 489-519. [Google Scholar]

Mäkelä, K., Barner-Rasmussen, W., Ehrnrooth, M., \& Koveshnikov, A. (2019). Potential and recognized boundary spanners in multinational corporations. Journal of World Business, 54(4), 335-349. [Google Scholar] [CrossRef]

Mazur-Wierzbicka, E. (2019). Human Resources as Fundamental Element Determining the Development of Innovation. Marketing and Management of Innovations, 1, 335-356. [Google Scholar] [CrossRef]

Onuferova, E., Cabinova, V., \& Vargova, T. D. (2020). Analysis of modern methods for increasing and managing the financial prosperity of businesses in the context of performance: a case study of the tourism sector in Slovakia. Oeconomia Copernicana, 11(1), 95-116. [Google Scholar] [CrossRef]

Pietruszka-Ortyl, A. (2019). The Impact of Organizational Culture for Company's Innovation Strategy. Marketing and Management of Innovations, 3, 178-192. [Google Scholar] [CrossRef]

Poklembova, Z. (2019). Mindfulness and Self-Compassionin the Practice of Social Work. Journal Socioterapie, 5(2), 27-32. Retrieved from [Link]

Primecz, H., Mahadevan, J., \& Romani, L. (2016). Why is cross-cultural management scholarship blind to power relations? Investigating ethnicity, language, gender and religion in power-laden contexts. Cross Cultural Management, 16(2), 127-136. [Google Scholar] [CrossRef]

Ristic, M. R., Selakovic, M., \& Qureshi, T. M. (2017). Employee motivation strategies and creation of supportive work environment in societies of post-socialist transformation. Polish journal of management studies, 15. [Google Scholar] [CrossRef]

Romani, L., Barmeyer, C., Primecz, H., \& Pilhofer, K. (2018). Cross-cultural management studies: state of the field in the four research paradigms. International Studies of Management \& Organization, 48(3), 247-263. [Google Scholar] [CrossRef]

Schotter, A. P., Mudambi, R., Doz, Y. L., \& Gaur, A. (2017). Boundary spanning in global organizations. Journal of Management Studies, 54(4), 403-421. [Google Scholar] [CrossRef]

Sokolovska, A., Zatonatska, T., Stavytskyy, A., Lyulyov, O., \& Giedraitis, V. R. (2020). The impact of globalization and international tax competition on tax policies. Research in world economy, 11(4), 1-15. [Google Scholar] [CrossRef]

Пітер Галло, Ph.D., доцент, Пряшівський університет, Словаччина

Беата Балогова, Ph.D., професор, Пряшівський університет, Словаччина

Богуслава Міхалкова, Ph.D., професор, Економічний університет в Братиславі, Словаччина

Міжкультурний менеджмент як елемент інноваційного управління

В умовах інтенсифікації глобалізаційних процесів, сучасні компанії функціонують та комунікують з міжнародними стейкхолдерами у відкритому мультикультурному середовищі. Міжкультурний менеджмент є невід'ємною та важливою складової системи управління міжнародної компанії. У статті авторами теоретично обгурнтовано, що ефективний міжкультурний менеджмент забезпечує інноваційність у взаємовідносинах між працівниками, що, у свою чергу, сприяє досягненню цілей функціонування компанії. Метою статті $є$ дослідження впливу рівня еффективності міжкультурного менеджменту на взаємовідносини між локальними та іноземними працівниками та/або менеджерами. Детерміновану вибірку даних сформовано на основі результатів опитування працівників IT-компаній. У ході дослідження застосовано тест КраскелаУолліса для перевірки висунутих гіпотез. Емпіричні результати засвідчили статистично значущі відмінності у співвідношенні між обізнаністю в культурних відмінностях компанії та досвідом роботи. Розрахункове значення $p=0,04728$ свідчить про те, що працівники з більшим досвідом роботи у мультикультурних компаніях, мають кращі знання про специфіку їі роботи у кроскультурному середовищі. При цьому розрахункове значення $\mathrm{p}=0,6539$ не підтвердило гіпотезу щодо впливу рівня професійної підготовки працівників на сприйняття культурних відмінностей. У статті авторами наголошено, що процес комунікації працівників та стейкхолдерів у міжкультурному середовищі супроводжується низкою конфоліктів. Однак, емпіричні результати не підтвердили взаємозв'язок між виникненням конфліктів на основі культурних відмінностей та професійною підготовкою працівників $(\mathrm{p}=0,1)$. Результати дослідження мають теоретичне значення та можуть бути прийняті до впровадження в міжнародних компаніях для запобігання виникненню конфліктів через культурні відмінності.

Ключові слова: міжкультурний менеджент, міжкультурна комунікація, міжнародна компанія, співробітники, культурні відмінності. 